НАУКОВО-ДОСЛИДНИЙ ПНСТИТУТ ХОГОКЗ

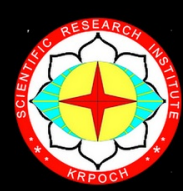

IO. B. MEJЫHIIK

\title{
ПЕДАГОГІЧНА МАЙСТЕРНІСТЬ: СИЛАБУС
}

навчально-методичний посібник 


\title{
НАУКОВО-ДОСЛІДНИЙ ІНСТИТУТ ХОГОКЗ
}

\author{
МЕЛЬНИК Юрій Борисович
}

\section{ПЕДАГОГІЧНА МАЙСТЕРНІСТЬ: СИЛАБУС}

навчально-методичний посібник

\author{
Харків \\ "ХОГОКЗ" \\ 2018
}


УДК 37.091.315.7:37.091.12:005.963(072)

DOI 10.26697/SRI.KRPOCH/Melnyk.Yu.1.2018

M 48

Рекомендовано

Вченою радою

Науково-дослідного інституту ХОГОКЗ

(протокол № 1 від 22.04.2018р.)

Автор - укладач

Мельник Ю. Б.

доктор філософії з освітніх наук $(\mathrm{PhD})$, доцент

Рецензенти:

Нагаєв В. М. - доктор педагогічних наук, професор, директор Харківського наукового центру дидактики менеджмент-освіти

Костіна В. В. - кандидат педагогічних наук, доцент, Харківський національний педагогічний університет імені Г. С. Сковороди; Науково-дослідний інститут ХОГОКЗ

М 48 Мельник Ю. Б. Педагогічна майстерність: силабус: навч.-метод. посіб. Харків: ХОГОКЗ. 2018. 26 c. doi:10.26697/SRI.KRPOCH/Melnyk.Yu.1.2018

Навчально-методичний посібник "Педагогічна майстерність: силабус" розкриває основні положення вивчення навчальної дисципліни "Педагогічна майстерність". Посібник містить інформацію, яка дозволяє здобувачам ознайомитися 3 вимогами до вивчення цього курсу, метою та завданнями навчальної дисципліни, змістом і календарно-тематичним планом вивчення, переліком тем для самостійної роботи, політикою та критеріями оцінювання, літературними посиланнями. Посібник може використовуватись для підготовки магістрів, студентів первинної спеціалізації, слухачів післядипломної освіти, перепідготовки та підвищення кваліфікації в системі педагогічної освіти.

УДК 37.091.315.7:37.091.12:005.963(072)

Видано за рахунок автора.

(C) Мельник Ю. Б., 2018.

(C) ХОГОКЗ, оформлення, 2018. 


\section{MICT}

ВСТУП....................................................... 4

1. Опис навчальної дисципліни.................................... 5

2. Мета та завдання навчальної дисципліни....................... 6

3. Зміст навчальної дисципліни (анотація навчальної

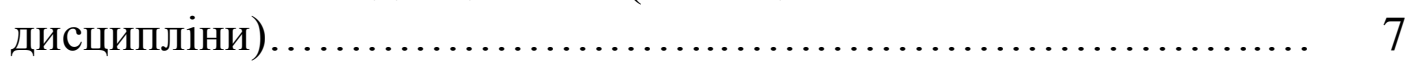

4. Календарно-тематичний план вивчення дисципліни............. 8

5. Самостійна робота...................................... 12

6. Політика курсу та оцінювання.............................. 14

7. Критерії оцінювання знань здобувачів ........................ 19

8. Питання до підсумкового контролю......................... 21

ЛІТЕРАТУРА............................................... 24 


\section{ВСТУП}

Навчально-методичний посібник "Педагогічна майстерність: силабус" розкриває основні положення вивчення навчальної дисципліни "Педагогічна майстерність".

Посібник містить інформацію, яка дозволяє здобувачам ознайомитися 3 вимогами до вивчення цього курсу, метою та завданнями навчальної дисципліни, змістом i календарно-тематичним планом вивчення, переліком тем для самостійної роботи, політикою та критеріями оцінювання, літературними посиланнями.

Посібник може використовуватись для підготовки магістрів, студентів первинної спеціалізації, слухачів післядипломної освіти, перепідготовки та підвищення кваліфікації в системі педагогічної освіти. 
Мельник Ю. Б.

\section{1. Опис навчальної дисципліни}

\begin{tabular}{|l|c|}
\hline \multicolumn{2}{|c|}{ Інформація про викладача } \\
\hline Ім'я та прізвище & Юрій МЕЛЬНИК \\
\hline Наукова ступінь & доктор філософії з освітніх наук (PhD) \\
\hline Вчене звання & доцент \\
\hline Посада & директор \\
\hline Місце роботи & Освітній центр ХОГОКЗ \\
\hline Структурний підрозділ/кафедра & https://institute.culturehealth.org \\
\hline Контакти & sci.res.institute@gmail.com \\
\hline Етаі & Консультації \\
\hline \multicolumn{1}{|c|}{} \\
\hline Час & \\
\hline Місце & \\
\hline
\end{tabular}

\begin{tabular}{|c|c|c|}
\hline Найменування показників & $\begin{array}{l}\text { Рівень освіти, } \\
\text { галузь знань, } \\
\text { спеціальність }\end{array}$ & $\begin{array}{c}\text { Характеристика навчальної } \\
\text { дисципліни }\end{array}$ \\
\hline Рівень вищої освіти & $\begin{array}{c}\text { другий } \\
\text { (магістерський) }\end{array}$ & денна форма навчання \\
\hline Статус дисципліни & базовий & цикл загальної підготовки \\
\hline Мова викладання & & українська \\
\hline Кількість кредитів - 3 & $\begin{array}{c}\text { Галузь знань: } \\
\ldots\end{array}$ & \\
\hline Блоків змістових модулів - 1 & \multirow{3}{*}{$\begin{array}{c}\text { Спеціальність: } \\
\ldots\end{array}$} & \multirow{2}{*}{ Рік підготовки: 1-й } \\
\hline Змістових модулів - 5 & & \\
\hline ІНДЗ - не передбачене & & Семестр: 1 та 2-й \\
\hline \multirow{5}{*}{ Загальна кількість годин - 90} & & Лекції - 16 год. \\
\hline & & Практичні, семінарські - 16 год. \\
\hline & & Групові - 14 год. \\
\hline & & Самостійна робота - 42 год. \\
\hline & & Вид контролю: залік - 2 год. \\
\hline
\end{tabular}




\section{2. Мета та завдання навчальної дисципліни}

Мета курсу - ознайомити слухачів 3 основними положеннями педагогічної майстерності та сучасними педагогічними технологіями в освіті, а також оволодіння комплексом професійних умінь та навичок необхідних для здійснення їхніх майбутніх обов'язків, повноважень та функцій.

Згідно з вимогами освітньої програми здобувачі вищої освіти повинні:

Знати: суть основних педагогічних дефініцій, педагогічної культури та педагогічної майстерності викладача у ЗВО, а також культури педагогічного спілкування і розвитку комунікативних умінь майбутнього педагога; суть технологічного підходу в освіті; загальні основи педагогічної техніки, як складової педагогічної майстерності викладача; основи психолого-педагогічних та етичних умов майстерної взаємодії в педагогічному спілкуванні;

Уміти: застосовувати отримані знання у навчально-виховній діяльності; формувати педагогічну культуру майбутніх фахівців та вміння відстоювати свою позицію з педагогічних і соціально-політичних проблем, вести діалог і дискусію, виважено і переконливо доводити свою позицію до відома інших тощо;

Володіти та відтворювати: досвід практичної педагогічної діяльності шляхом самостійного вибору та застосування типових методів діяльності в галузі інтеграційних процесів в освітній галузі для супроводження навчально-виховної діяльності у звичайних (стандартних) умовах; вирішувати фахові завдання шляхом застосування нових форм і методів організації та управління освітнім процесом та організації соціального середовища в інтересах розв'язання педагогічних завдань;

Бути ознайомленим із понятійним апаратом, необхідним для організації навчально-виховної діяльності за фахом, принципами побудови i функціонування педагогічного супроводження щодо розв'язання задач морального забезпечення навчально-виховної діяльності; теоретичними положеннями педагогіки та інформаційного забезпечення навчально-виховної діяльності; практикою організації діяльності педагогів у закладах вищої освіти достатньої для виконання у повному обсязі своїх функціональних обов'язків, формування і впровадження власних поглядів, можливих напрямів розвитку педагогічного забезпечення. 


\section{3. Зміст навчальної дисципліни (анотація навчальної дисципліни).}

Предмет вивчення навчальної дисципліни: освітній процес професійної підготовки спеціаліста, вивчення парадигм, законів та закономірностей, які існують у вищій школі; розробка на цій основі методологічних, теоретичних, технологічних i методичних проблем становлення сучасного висококваліфікованого спеціаліста.

У межах цього курсу слухачі продовжують формувати інтегральну компетентність, особистісні та професійні уміння та навички, а саме: ознайомлюються з системою вищої освіти, оволодівають основами дидактики вищої школи, сучасними вимогами до організації занять у закладі вищої освіти, удосконалюють навички необхідних для здійснення кола їхніх майбутніх обов'язків, повноважень та функцій, зокрема: організаційної, обліковоаналітичної, планової, контрольної, технологічної, навчально-методичної, науково-дослідної та ін.

Міждисциплінарні зв'язки з дисциплінами.

Слухачі працюють з інформацією, зокрема 3 використанням мережі Інтернет, виконують усні та письмові завдання, виступають 3 промовами i презентаціями, підготовленими ними як групові та/або індивідуальні проекти, моделюють різні формати професійного спілкування (лекція, семінар, групове та практичне заняття, контрольна робота) у межах тем змістових модулів «Педагогічна культура та педагогічна майстерність викладача», «Технологічний підхід в освіті», «Загальні основи педагогічної техніки», «Професійні та особистісні якості викладача», «Психолого-педагогічні та етичні умови майстерної взаємодії в педагогічному спілкуванні» та ін. 


\section{4. Календарно-тематичний план вивчення дисципліни.}

\begin{tabular}{|c|c|c|c|c|c|}
\hline \multirow[b]{3}{*}{ Назва модулів і тем } & \multirow{2}{*}{\multicolumn{4}{|c|}{$\begin{array}{c}\text { Форми організації } \\
\text { навчання, вид } \\
\text { навчальних занять } \\
\text { кількість годин } \\
\text { денна } \\
\end{array}$}} & \multirow[b]{3}{*}{$\begin{array}{c}\text { Завдання для } \\
\text { самостійної роботи }\end{array}$} \\
\hline & & & & & \\
\hline & : & 商 & 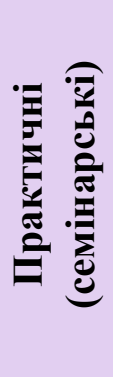 & שֶ & \\
\hline \multicolumn{6}{|c|}{ Змістовий модуль 1. Педагогічна культура та майстерність викладача ЗВО } \\
\hline $\begin{array}{l}\text { Заняття 1. Предмет і завдання курсу } \\
\text { "ПМ" }\end{array}$ & 2 & & & 4 & $\begin{array}{l}\text { 1. Сутнісні ознаки } \\
\text { педагога } 3 \mathrm{BO} .\end{array}$ \\
\hline $\begin{array}{l}\text { Заняття 2. Педагогічна культура та } \\
\text { педагогічна майстерність викладача } \\
\text { ЗВО }\end{array}$ & 2 & & & 4 & $\begin{array}{l}\text { 1. Педагогічна } \\
\text { культура та автори- } \\
\text { тет викладача 3ВО. } \\
\text { 2. Шляхи } \\
\text { формування та } \\
\text { реалізація педаго- } \\
\text { гічної майстерності. }\end{array}$ \\
\hline $\begin{array}{l}\text { Заняття 3. Педагогічна культура та } \\
\text { педагогічна майстерність }\end{array}$ & & & 4 & & \\
\hline $\begin{array}{l}\text { Заняття 4. Педагогічна майстерність і } \\
\text { особистість викладача }\end{array}$ & & 4 & & 2 & $\begin{array}{l}\text { 1. Педагогічна } \\
\text { майстерність праці } \\
\text { педагога. } \\
\text { 2. Психологічні } \\
\text { особливості } \\
\text { особистість. }\end{array}$ \\
\hline \multicolumn{6}{|c|}{ Модульний контроль } \\
\hline \multicolumn{6}{|c|}{ Змістовий модуль 2. Технологічний підхід в освіті } \\
\hline Заняття 1. Сучасні технології навчання & 2 & & & 4 & $\begin{array}{l}\text { 1. Освітні інфор- } \\
\text { маційні технології. }\end{array}$ \\
\hline $\begin{array}{l}\text { Заняття 2. Сучасні технології } \\
\text { навчання. }\end{array}$ & & & 4 & & \\
\hline $\begin{array}{l}\text { Заняття 3. Педагогічна характеристика } \\
\text { провідних видів навчальних занять. }\end{array}$ & & 4 & & 2 & $\begin{array}{l}\text { 1. Специфіка } \\
\text { проведення лекції. } \\
\text { 2. Специфіка } \\
\text { проведення } \\
\text { групового заняття. }\end{array}$ \\
\hline
\end{tabular}




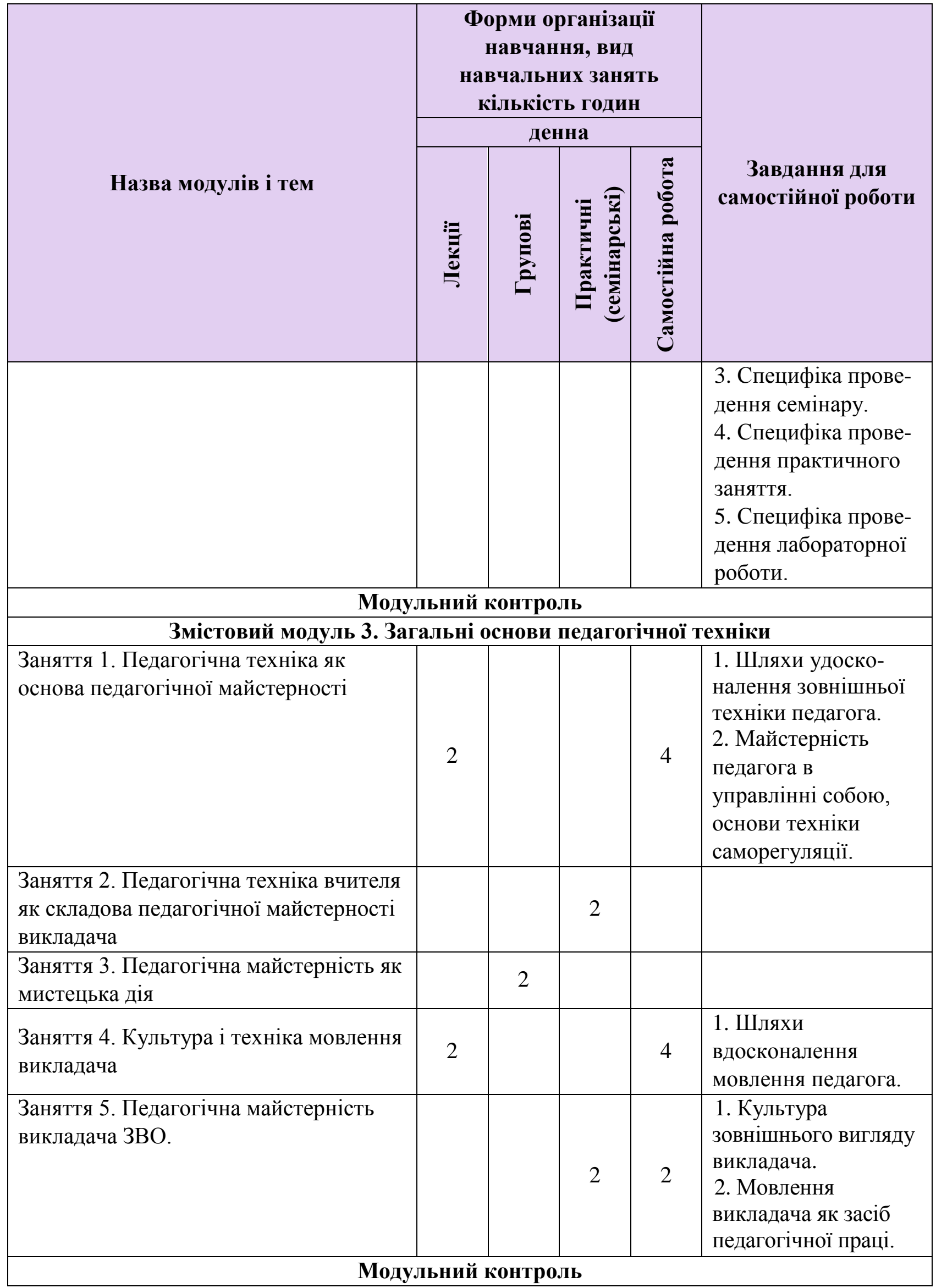




\begin{tabular}{|c|c|c|c|c|c|}
\hline \multirow[b]{3}{*}{ Назва модулів і тем } & \multirow{2}{*}{\multicolumn{4}{|c|}{$\begin{array}{c}\text { Форми організації } \\
\text { навчання, вид } \\
\text { навчальних занять } \\
\text { кількість годин } \\
\text { денна } \\
\end{array}$}} & \multirow[b]{3}{*}{$\begin{array}{c}\text { Завдання для } \\
\text { самостійної роботи }\end{array}$} \\
\hline & & & & & \\
\hline & 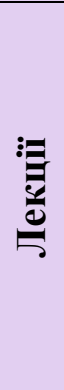 & 产 & 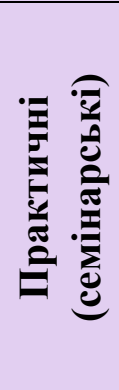 & 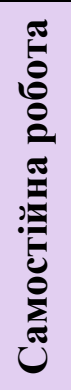 & \\
\hline \multicolumn{6}{|c|}{ Блок змістового модуль 2. Професійні та особистісні якості викладача } \\
\hline \multicolumn{6}{|c|}{ Змістовий модуль 4. Професійні та особистісні якості викладача ЗВО. } \\
\hline Заняття 1. Характеристика викладача & 2 & & & 4 & $\begin{array}{l}\text { 1. Професіограма } \\
\text { педагога. }\end{array}$ \\
\hline $\begin{array}{l}\text { Заняття 2. Майстерність педагога ЗВО } \\
\text { в управлінні собою }\end{array}$ & & & 2 & & \\
\hline $\begin{array}{l}\text { Заняття 3. Майстерність педагогічного } \\
\text { спілкування }\end{array}$ & 2 & & & 4 & $\begin{array}{l}\text { 1. Розвиток } \\
\text { комунікативних } \\
\text { умінь і здібностей } \\
\text { педагога ЗВО. }\end{array}$ \\
\hline \multicolumn{6}{|l|}{$\begin{array}{l}\text { Заняття 4. Культура педагогічного } \\
\text { спілкування. Розвиток комунікативних } \\
\text { умінь майбутнього педагога 3ВО }\end{array}$} \\
\hline $\begin{array}{l}\text { Заняття 5. Основи мімічної та } \\
\text { пантомімічної виразності педагога }\end{array}$ & & 2 & & 2 & $\begin{array}{l}\text { 1. Виконання вправ } \\
\text { на контроль та } \\
\text { корекцію правильної } \\
\text { осанки, пози, руху. } \\
\text { 2. Виконання вправ } \\
\text { на вироблення } \\
\text { навичок } \\
\text { невербальної } \\
\text { поведінки педагога. } \\
\text { 3. Виконання вправ } \\
\text { на розвиток } \\
\text { розуміння експресій } \\
\text { психічного стану } \\
\text { особистості. } \\
\text { 4. Виконання вправ } \\
\text { на розвиток основ } \\
\text { мімічної та } \\
\text { пантомімічної } \\
\text { виразності. }\end{array}$ \\
\hline \multicolumn{6}{|c|}{ Модульний контроль } \\
\hline
\end{tabular}




\begin{tabular}{|c|c|c|c|c|c|}
\hline \multirow[b]{3}{*}{ Назва модулів і тем } & \multirow{2}{*}{\multicolumn{4}{|c|}{$\begin{array}{c}\text { Форми організації } \\
\text { навчання, вид } \\
\text { навчальних занять } \\
\text { кількість годин } \\
\text { денна } \\
\end{array}$}} & \multirow[b]{3}{*}{$\begin{array}{c}\text { Завдання для } \\
\text { самостійної роботи }\end{array}$} \\
\hline & & & & & \\
\hline & 音 & 兽 & 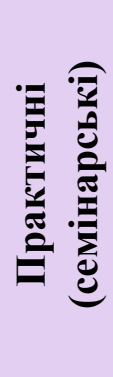 & 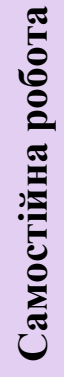 & \\
\hline \multicolumn{6}{|c|}{$\begin{array}{c}\text { Змістовий модуль 5. Психолого-педагогічні та етичні умови майстерної взасмодії в } \\
\text { педагогічному спілкуванні }\end{array}$} \\
\hline $\begin{array}{l}\text { Заняття 1. Педагогічний такт та етика } \\
\text { поведінки педагога }\end{array}$ & 2 & & & 4 & $\begin{array}{l}\text { 1. Особливості взає- } \\
\text { модії педагога з під- } \\
\text { леглими, як мають } \\
\text { "складний характер". }\end{array}$ \\
\hline $\begin{array}{l}\text { Заняття 2. Психолого-педагогічні } \\
\text { умови майстерної взаємодії в } \\
\text { педагогічному спілкуванні }\end{array}$ & & & & 2 & $\begin{array}{l}\text { 1. Особистість } \\
\text { педагога як інстру- } \\
\text { мент впливу в педа- } \\
\text { гогічній взаємодії. } \\
\text { 2. Способи комуні- } \\
\text { кативного впливу: } \\
\text { переконування та } \\
\text { навіювання. } \\
\text { 3. Стратегії взаємо- } \\
\text { дії у спілкуванні як } \\
\text { характеристика } \\
\text { інтерактивного ком- } \\
\text { понента педагогіч- } \\
\text { ної взаємодії. } \\
\text { 4. Педагогічний такт } \\
\text { як почуття міри в } \\
\text { застосуванні засобів } \\
\text { педагогічного впливу } \\
\text { на підлеглих, важлива } \\
\text { умова формування } \\
\text { авторитету майбут- } \\
\text { нього педагога. } \\
\text { 5. Шляхи } \\
\text { формування } \\
\text { педагогічного такту. }\end{array}$ \\
\hline $\begin{array}{l}\text { Заняття 3. Конфлікти у педагогічній } \\
\text { взаємодії, шляхи їхнього запобігання } \\
\text { та стратегії вирішення }\end{array}$ & & 2 & & & \\
\hline \multicolumn{6}{|c|}{ Модульний контроль } \\
\hline
\end{tabular}




\section{5. Самостійна робота.}

Підготовка до лекцій передбачає самостійне вивчення теоретичного матеріалу з кожної теми, наданого в основній та додатковій літературі, конспекті лекцій. При цьому необхідно звернути увагу на необхідність чіткого засвоєння основних термінів та понять, розуміння їх змісту, використання теоретичних положень для практичного вирішення задач.

Підготовка до практичних (семінарських) занять здійснюється шляхом ознайомлення слухачів з основними теоретичними положеннями до кожного заняття, нормативною документацією, літературою, методикою виконання вправ.

Перелік тем, які здобувач повинен вивчити самостійно (3 рекомендованою літературою):

1. Сутнісні ознаки педагога 3ВО.

2. Педагогічна культура та авторитет викладача 3ВО.

3. Шляхи формування та реалізація педагогічної майстерності.

4. Педагогічна майстерність праці педагога.

5. Психологічні особливості особистість.

6. Освітні інформаційні технології.

7. Специфіка проведення лекції.

8. Специфіка проведення групового заняття.

9. Специфіка проведення семінару.

10. Специфіка проведення практичного заняття.

11. Специфіка проведення лабораторної роботи.

12. Шляхи удосконалення зовнішньої техніки педагога.

13. Майстерність педагога в управлінні собою, основи техніки саморегуляції.

14. Шляхи вдосконалення мовлення педагога.

15. Культура зовнішнього вигляду викладача.

16. Мовлення викладача як засіб педагогічної праці.

17. Професіограма педагога.

18. Розвиток комунікативних умінь і здібностей педагога ЗВО.

19. Виконання вправ на контроль та корекцію правильної осанки, пози, pyxy.

20. Виконання вправ на вироблення навичок невербальної поведінки педагога.

21. Виконання вправ на розвиток розуміння експресій психічного стану особистості.

22. Виконання вправ на розвиток основ мімічної та пантомімічної виразності. 


\section{Мельник Ю. Б.}

23. Особливості взаємодії педагога 3 підлеглими, як мають "складний характер".

24. Особистість педагога як інструмент впливу в педагогічній взаємодії.

25. Способи комунікативного впливу: переконування та навіювання.

26. Стратегії взаємодії у спілкуванні як характеристика інтерактивного компонента педагогічної взаємодії.

27. Педагогічний такт як почуття міри в застосуванні засобів педагогічного впливу на підлеглих, важлива умова формування авторитету майбутнього педагога.

28. Шляхи формування педагогічного такту.

Для самостійного вивчення вищенаведеного переліку тем слухачам запропоновано використовувати рекомендовану основну та додаткову літературу, інформаційні ресурси до цього курсу, а також вони можуть застосовувати іншу літературу та джерела 3 тематики курсу, яких немає серед рекомендованих.

\section{Вказівки до самостійної роботи.}

Зміст самостійної роботи для здобувачів вищої освіти денної форми

\section{навчання:}

1. Поглиблене вивчення питань за темами відповідно до методичних вказівок.

2. Систематична підготовка до семінарських занять відповідно до запропонованих питань (переліку питань надається) за тематикою курсу.

3. Опрацювання лекційного матеріалу та семінарських занять у конспекті.

4. Вивчення запропонованої базової та допоміжної літературу з питань курсу.

5. Самостійна підготовка до модульного контролю та заліку.

У процесі самопідготовки за темами курсу особливу увагу слухачів слід звернути на засвоєння основних понять і термінів.

Обов'язковим вважається ведення слухачами робочого конспекту, який повинен містити план, тезисний або розгорнутий огляд питань, що віднесені для самостійного опрацювання, а також визначення основних понять і термінів.

У процесі вивчення курсу для поточного контролю самостійної роботи слухачів та якості засвоєння ними матеріалу викладач використовує:

- опитування слухачів під час лекційних та семінарських занять;

- залучення слухачів до творчих завдань, розробкою презентацій з тем семінарських занять;

- залучення слухачів до участі у науково-дослідній роботі, участі у конференціях, олімпіадах, конкурсах, а також підготовкою тез і наукових статей з питань курсу;

- перевірку робочих конспектів;

- проведення поточних контрольних робіт;

- тестування та модульного контролю. 


\section{Педагогічна майстерність: силабус}

\section{6. Політика курсу та оцінювання.}

\section{Міжсесійне оцінювання (поточна та тематична перевірка)}

Поточне оцінювання здійснюється за кожним завданням в межах модулів. Оцінюються і завдання, виконувані в аудиторії, і завдання, виконувані під час самостійної роботи на підгрунті перевірки конспектів.

Загальні критерії оцінок:

"відмінно" - слухач має зробити виступ за одним з питань семінару, приймати активну участь в обговорюванні виступів інших учасників, ставити витання, давати відповіді. Конспект повинен містити всю основну інформацію 3 певної теми, мати узагальнено-логіні схеми, таблиці тощо.

“добре" - слухач має зробити виступ за одним з питань семінару. Конспект повинен містити всю основну інформацію з певної теми.

"задовільно" - слухач має приймати участь в обговорюванні виступів інших учасників. Конспект повинен містити основну інформацію з певної теми.

"незадовільно" - слухач не готовий до заняття, не приймає участь в обговорюванні виступів інших учасників. Конспект не містити основну інформацію з певної теми.

\section{Підсумкове оцінювання (рубіжний та заключний контроль)}

Метою заліку $є$ контроль сформованості в слухачів системи знань про освіту у вищій школі, розкрити концепції, основні теорії, методологію, технології та методики викладання навчальних дисциплін в університетській освіті, а також оволодіння комплексом професійних умінь та навичок необхідних для здійснення їхніх майбутніх обов'язків, повноважень та функцій.

Залік здійснюється на підгрунті суми набраних балів отриманих підчас міжсесійного оцінювання (поточна та тематична перевірка), виконання завдань 3 курсу, ведення конспекту та/або за результатом виконання тестових завдань.

1. Кількість балів за ведення конспекту (самопідготовку) становіть від 0 до 60 балів.

2. Кількість балів за аудиторну та наукову діяльність (у межах вивчення курсу) становити від 0 до 65 балів.

\section{Політика курсу}

- Курс передбачає індивідуальну та групову роботу.

- Середовище в аудиторії $\epsilon$ дружнім, творчим, відкритим до конструктивної критики.

- Усі завдання, передбачені програмою, мають бути виконані в становлений термін.

- Якщо слухач відсутній з поважної причини, він/вона презентують виконані завдання під час самостійної підготовки та консультації.

- Під час роботи над проектом, виконання письмових робіт, складання тестів не допустимо порушення академічної доброчесності.

- Всі виконані роботи мають бути авторськими, оригінальними. 
Політика щцодо дедлайнів (останній строк, коли повинно бути виконано завдання) та перескладання:

Роботи, які здаються із порушенням термінів без поважних причин, оцінюються на нижчу оцінку. Перескладання модулів відбувається із дозволу завідувача кафедри за наявності поважних причин (хвороба та ін.).

\section{Політика щцоо академічної доброчесності:}

Усі письмові роботи перевіряються на наявність плагіату і допускаються до захисту із коректними текстовими запозиченнями не більше 20\%. Списування під час заліку заборонені (в т.ч. із використанням мобільних пристроїв).

\section{Політика щодо відвідування та поведінки в аудиторії:}

Відвідування занять $є$ обов'язковим компонентом оцінювання, за кожне практичне заняття слухач отримує оцінку. За об'єктивних причин (наприклад, хвороба, міжнародне стажування тощо) навчання може відбуватись в он-лайн формі за погодженням із керівником курсу.

Вивчення цього курсу передбачає повне, часткове або опосередковане формування відповідних компетентностей з курсу «Педагогічна майстерність».

Компетентності, які слухач набуде в результаті навчання наведені в таблиці 1.

Таблиця 1.

\section{Компетентності та оцінювання рівня їх досягнення слухачами}

\begin{tabular}{|c|c|c|c|}
\hline Група & Компетентність & $\begin{array}{c}\text { Ступінь сформованості } \\
\text { компетентності }\end{array}$ & Оцінювання \\
\hline \multirow{5}{*}{ 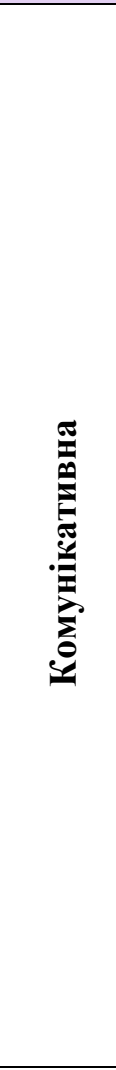 } & $\begin{array}{l}\text { здатність до аналізу та } \\
\text { синтезу основних положень } \\
\text { керівних документів } \\
\text { системи вищої освіти }\end{array}$ & $\begin{array}{l}\text { Опосередковано, під час } \\
\text { виконання завдань із пошуку } \\
\text { та опрацювання інформації у } \\
\text { межах курсу. }\end{array}$ & $\begin{array}{l}\text { Міжсесійне } \\
\text { (поточна та тематична } \\
\text { перевірка), виконання } \\
\text { завдань } 3 \text { курсу. }\end{array}$ \\
\hline & $\begin{array}{l}\text { уміння організовувати і } \\
\text { планувати свою навчально- } \\
\text { виховну діяльність }\end{array}$ & $\begin{array}{l}\text { Опосередковано, шляхом } \\
\text { організації та планування } \\
\text { власного навчання, } \\
\text { виконання завдань. }\end{array}$ & $\begin{array}{l}\text { Міжсесійне } \\
\text { (поточна та тематична } \\
\text { перевірка), виконання } \\
\text { завдань з курсу. } \\
\text { Перевірка конспектів. }\end{array}$ \\
\hline & $\begin{array}{l}\text { базові знання з педагогічної } \\
\text { культури та педагогічної } \\
\text { майстерності викладача }\end{array}$ & $\begin{array}{l}\text { Опосередковано, під час } \\
\text { професійного спілкування та } \\
\text { участі в: лекціях, семінарах, } \\
\text { групових та практичних } \\
\text { заняттях. }\end{array}$ & $\begin{array}{l}\text { Міжсесійне } \\
\text { (поточна та тематична } \\
\text { перевірка), виконання } \\
\text { завдань з курсу. }\end{array}$ \\
\hline & $\begin{array}{l}\text { базові знання з професії } \\
\text { щодо майстерної взаємодії } \\
\text { в педагогічному } \\
\text { спілкуванні }\end{array}$ & $\begin{array}{l}\text { Опосередковано, під час } \\
\text { професійного спілкування та } \\
\text { участі в: лекціях, семінарах, } \\
\text { групових та практичних } \\
\text { заняттях. }\end{array}$ & $\begin{array}{l}\text { Міжсесійне } \\
\text { (поточна та тематична } \\
\text { перевірка), виконання } \\
\text { завдань з курсу. }\end{array}$ \\
\hline & $\begin{array}{l}\text { комунікативні навички } 3 \\
\text { рідної мови }\end{array}$ & $\begin{array}{l}\text { Опосередковано, під час } \\
\text { професійного спілкування та } \\
\text { участі в: лекціях, семінарах, } \\
\text { групових та практичних } \\
\text { заняттях. }\end{array}$ & $\begin{array}{l}\text { Міжсесійне } \\
\text { (поточна та тематична } \\
\text { перевірка), виконання } \\
\text { завдань з курсу. } \\
\text { Перевірка конспектів. }\end{array}$ \\
\hline
\end{tabular}




\begin{tabular}{|c|c|c|c|}
\hline Група & Компетентність & $\begin{array}{c}\text { Ступінь сформованості } \\
\text { компетентності }\end{array}$ & Оцінювання \\
\hline & $\begin{array}{l}\text { елементарні комп’ютерні } \\
\text { навички }\end{array}$ & $\begin{array}{l}\text { Опосередковано, під час } \\
\text { виконання завдань із пошуку } \\
\text { та опрацювання інформації у } \\
\text { межах курсу. }\end{array}$ & $\begin{array}{l}\text { Міжсесійне } \\
\text { (поточна та тематична } \\
\text { перевірка), виконання } \\
\text { завдань } 3 \text { курсу. }\end{array}$ \\
\hline & $\begin{array}{l}\text { навички оперування } \\
\text { інформацією (здатність } \\
\text { отримувати та аналізувати } \\
\text { інформацію з різних } \\
\text { джерел) }\end{array}$ & $\begin{array}{l}\text { Опосередковано, під час } \\
\text { виконання завдань із пошуку } \\
\text { та опрацювання інформації у } \\
\text { межах курсу. }\end{array}$ & $\begin{array}{l}\text { Міжсесійне } \\
\text { (поточна та тематична } \\
\text { перевірка), виконання } \\
\text { завдань } 3 \text { курсу. } \\
\text { Перевірка конспектів. }\end{array}$ \\
\hline & $\begin{array}{l}\text { здатність вирішувати } \\
\text { проблеми }\end{array}$ & $\begin{array}{l}\text { Опосередковано, шляхом } \\
\text { організації та планування } \\
\text { власного навчання, } \\
\text { виконання завдань. }\end{array}$ & $\begin{array}{l}\text { Міжсесійне } \\
\text { (поточна та тематична } \\
\text { перевірка), виконання } \\
\text { завдань } 3 \text { курсу. }\end{array}$ \\
\hline & $\begin{array}{l}\text { здатність приймати } \\
\text { рішення }\end{array}$ & $\begin{array}{l}\text { Опосередковано, під час } \\
\text { професійного спілкування та } \\
\text { участі в: лекціях, семінарах, } \\
\text { групових та практичних } \\
\text { заняттях. }\end{array}$ & $\begin{array}{l}\text { Міжсесійне } \\
\text { (поточна та тематична } \\
\text { перевірка), виконання } \\
\text { завдань } 3 \text { курсу. }\end{array}$ \\
\hline \multirow{6}{*}{ 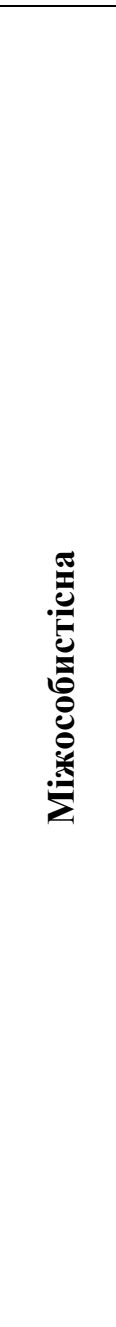 } & $\begin{array}{l}\text { здатність до критики та } \\
\text { самокритики }\end{array}$ & $\begin{array}{l}\text { Опосередковано, під час } \\
\text { професійного спілкування та } \\
\text { участі в: лекціях, семінарах, } \\
\text { групових та практичних } \\
\text { заняттях. }\end{array}$ & $\begin{array}{l}\text { Підсумкове } \\
\text { (рубіжний та } \\
\text { заключний контроль). } \\
\text { (Залік) }\end{array}$ \\
\hline & $\begin{array}{l}\text { здатність працювати в } \\
\text { команді }\end{array}$ & $\begin{array}{l}\text { Опосередковано, під час } \\
\text { професійного спілкування та } \\
\text { участі в: лекціях, семінарах, } \\
\text { групових та практичних } \\
\text { заняттях. }\end{array}$ & $\begin{array}{l}\text { Міжсесійне } \\
\text { (поточна та тематична } \\
\text { перевірка), виконання } \\
\text { завдань } 3 \text { курсу. }\end{array}$ \\
\hline & міжособистісні навички & $\begin{array}{l}\text { Опосередковано, під час } \\
\text { професійного спілкування та } \\
\text { участі в: лекціях, семінарах, } \\
\text { групових та практичних } \\
\text { заняттях. }\end{array}$ & $\begin{array}{l}\text { Міжсесійне } \\
\text { (поточна та тематична } \\
\text { перевірка), виконання } \\
\text { завдань } 3 \text { курсу. } \\
\text { Перевірка конспектів. }\end{array}$ \\
\hline & $\begin{array}{l}\text { здатність працювати в } \\
\text { міждисциплінарній команді }\end{array}$ & $\begin{array}{l}\text { Опосередковано, під час } \\
\text { професійного спілкування та } \\
\text { участі в: лекціях, семінарах, } \\
\text { групових та практичних } \\
\text { заняттях. }\end{array}$ & $\begin{array}{l}\text { Міжсесійне } \\
\text { (поточна та тематична } \\
\text { перевірка), виконання } \\
\text { завдань } 3 \text { курсу. }\end{array}$ \\
\hline & $\begin{array}{l}\text { здатність співпрацювати } 3 \\
\text { експертами в інших } \\
\text { предметних областях }\end{array}$ & $\begin{array}{l}\text { Опосередковано, під час } \\
\text { професійного спілкування та } \\
\text { участі в: лекціях, семінарах, } \\
\text { групових та практичних } \\
\text { заняттях. }\end{array}$ & $\begin{array}{l}\text { Міжсесійне } \\
\text { (поточна та тематична } \\
\text { перевірка), виконання } \\
\text { завдань з курсу. }\end{array}$ \\
\hline & $\begin{array}{l}\text { здатність сприймати } \\
\text { різноманітність та між } \\
\text { культурні відмінності }\end{array}$ & $\begin{array}{l}\text { Опосередковано, під час } \\
\text { професійного спілкування та } \\
\text { участі в: лекціях, семінарах, } \\
\text { групових та практичних } \\
\text { заняттях. }\end{array}$ & $\begin{array}{l}\text { Міжсесійне } \\
\text { (поточна та тематична } \\
\text { перевірка), виконання } \\
\text { завдань з курсу. }\end{array}$ \\
\hline
\end{tabular}




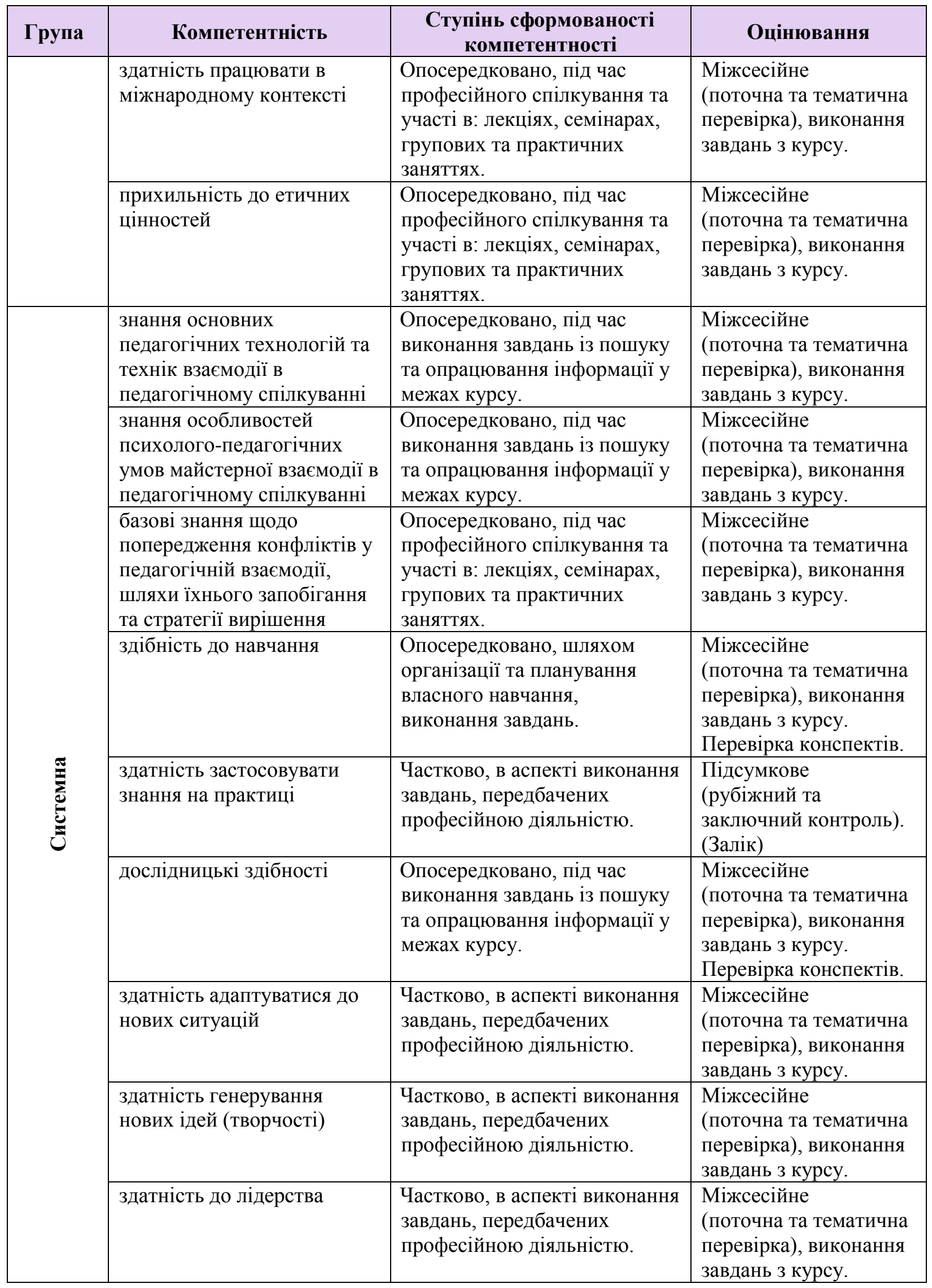


Педагогічна майстерність: силабус

\begin{tabular}{|c|c|c|c|}
\hline Група & Компетентність & $\begin{array}{c}\text { Ступінь сформованості } \\
\text { компетентності }\end{array}$ & Оцінювання \\
\hline & $\begin{array}{l}\text { розуміння культур та } \\
\text { звичаїв інших країн }\end{array}$ & $\begin{array}{l}\text { Опосередковано, шляхом } \\
\text { організації та планування } \\
\text { власного навчання, } \\
\text { виконання завдань. }\end{array}$ & $\begin{array}{l}\text { Міжсесійне } \\
\text { (поточна та тематична } \\
\text { перевірка), виконання } \\
\text { завдань } 3 \text { курсу. }\end{array}$ \\
\hline & $\begin{array}{l}\text { здатність працювати } \\
\text { автономно з педагогічною } \\
\text { та науковою літературою і } \\
\text { періодикою, постійно } \\
\text { підвищувати рівень } \\
\text { педагогічних та соціально- } \\
\text { політичних знань }\end{array}$ & $\begin{array}{l}\text { Опосередковано, шляхом } \\
\text { організації та планування } \\
\text { власного навчання, } \\
\text { виконання завдань. }\end{array}$ & $\begin{array}{l}\text { Міжсесійне } \\
\text { (поточна та тематична } \\
\text { перевірка), виконання } \\
\text { завдань } 3 \text { курсу. } \\
\text { Перевірка конспектів. }\end{array}$ \\
\hline & $\begin{array}{l}\text { здатність до розробки } \\
\text { проектів та керування ними }\end{array}$ & $\begin{array}{l}\text { Опосередковано, шляхом } \\
\text { організації та планування } \\
\text { власного навчання, } \\
\text { виконання завдань. }\end{array}$ & $\begin{array}{l}\text { Міжсесійне } \\
\text { (поточна та тематична } \\
\text { перевірка), виконання } \\
\text { завдань з курсу. }\end{array}$ \\
\hline & $\begin{array}{l}\text { здатність до ініціативи і } \\
\text { підприємництва }\end{array}$ & $\begin{array}{l}\text { Опосередковано, шляхом } \\
\text { організації та планування } \\
\text { власного навчання, } \\
\text { виконання завдань. }\end{array}$ & $\begin{array}{l}\text { Міжсесійне } \\
\text { (поточна та тематична } \\
\text { перевірка), виконання } \\
\text { завдань з курсу. }\end{array}$ \\
\hline & відповідальність за якість & $\begin{array}{l}\text { Частково, в аспекті виконання } \\
\text { завдань, передбачених } \\
\text { професійною діяльністю. }\end{array}$ & $\begin{array}{l}\text { Міжсесійне } \\
\text { (поточна та тематична } \\
\text { перевірка), виконання } \\
\text { завдань } 3 \text { курсу. } \\
\text { Перевірка конспектів. }\end{array}$ \\
\hline & прагнення до успіху & $\begin{array}{l}\text { Опосередковано, шляхом } \\
\text { організації та планування } \\
\text { власного навчання, } \\
\text { виконання завдань. }\end{array}$ & $\begin{array}{l}\text { Підсумкове } \\
\text { (рубіжний та } \\
\text { заключний контроль). } \\
\text { (Залік) }\end{array}$ \\
\hline
\end{tabular}




\section{7. Критерії оцінювання знань здобувачів.}

\section{Оцінювання знань здобувачів здійснюється відповідно до Положення “Про організацію освітнього процесу в НДІ ХОГОКЗ”.}

Таблиця 2.

\section{Шкала оцінювання: національна та ECTS}

\begin{tabular}{|c|c|c|c|}
\hline \multicolumn{3}{|c|}{ Оцінки } & \multirow[b]{2}{*}{ Критерії } \\
\hline $\begin{array}{c}\text { за } \\
\text { шкалою } \\
\text { ЕCTS }\end{array}$ & $\begin{array}{c}\text { за } \\
\text { національною } \\
\text { шкалою }\end{array}$ & $\begin{array}{c}\text { за } \\
\text { шкалою } \\
\text { закладу }\end{array}$ & \\
\hline $\begin{array}{c}\text { А } \\
\text { "Відмінно" }\end{array}$ & Відмінно & $90-100$ & $\begin{array}{l}\text { Здобувач виявив всебічні, систематичні та глибокі знання } \\
\text { навчального матеріалу дисципліни, передбаченого } \\
\text { програмою; опрацював основну та додаткову літературу, } \\
\text { рекомендовану програмою; проявив творчі здібності у } \\
\text { розумінні, логічному, стислому та ясному трактуванні } \\
\text { навчального матеріалу; засвоїв взаємозв’язок основних } \\
\text { понять дисципліни, їх значення для подальшої професійної } \\
\text { діяльності. }\end{array}$ \\
\hline $\begin{array}{c}\text { В } \\
\text { “Дуже добре” }\end{array}$ & \multirow{2}{*}{ Добре } & $82-89$ & $\begin{array}{l}\text { Здобувач виявив систематичні та глибокі знання вище } \\
\text { середнього рівня навчального матеріалу дисципліни; } \\
\text { продемонстрував уміння легко виконувати завдання, } \\
\text { передбачені програмою; опрацював літературу, } \\
\text { рекомендовану програмою; засвоїв взаємозв’язок основних } \\
\text { понять дисципліни, їх значення для подальшої професійної } \\
\text { діяльності. }\end{array}$ \\
\hline $\begin{array}{c}\text { C } \\
\text { "Добре" }\end{array}$ & & $74-81$ & $\begin{array}{l}\text { Здобувач виявив у цілому добрі знання навчального } \\
\text { матеріалу дисципліни при виконанні передбачених } \\
\text { програмою завдань, але припустив низку незначних } \\
\text { помилок; опрацював основну літературу, рекомендовану } \\
\text { програмою; показав систематичні знання } 3 \text { дисципліни; } \\
\text { здатний самостійно використовувати та поповнювати } \\
\text { знання у процесі навчання та професійної діяльності. }\end{array}$ \\
\hline $\begin{array}{c}\text { D } \\
\text { “Задовільно" }\end{array}$ & \multirow[b]{2}{*}{ Задовільно } & $64-73$ & $\begin{array}{l}\text { Здобувач виявив знання навчального матеріалу дисципліни } \\
\text { в обсязі, необхідному для подальшого навчання та } \\
\text { майбутньої професійної діяльності; виконав завдання, } \\
\text { передбачені програмою; ознайомився } 3 \text { основною } \\
\text { літературою, що зазначена у програмі; припустив значну } \\
\text { кількість помилок або недоліків у відповідях на запитання } \\
\text { співбесіди, тестування, при виконанні завдань тощо, які } \\
\text { може усунути самостійно. }\end{array}$ \\
\hline $\begin{array}{c}\text { Е } \\
\text { “Достатньо" }\end{array}$ & & $60-63$ & $\begin{array}{l}\text { Здобувач виявив мінімальні знання основного навчального } \\
\text { матеріалу дисципліни в обсязі, необхідному для } \\
\text { подальшого навчання та майбутньої професійної } \\
\text { діяльності; в основному виконував завдання, передбачені } \\
\text { програмою; ознайомився } 3 \text { основною літературою, що } \\
\text { зазначена у програмі; припустив значні помилки у } \\
\text { відповідях на запитання співбесіди, тестування, при } \\
\text { виконанні завдань тощо, які може усунути лише під } \\
\text { керівництвом та за допомогою викладача. }\end{array}$ \\
\hline
\end{tabular}


Педагогічна майстерність: силабус

\begin{tabular}{|c|c|c|c|}
\hline \multicolumn{3}{|c|}{ Оцінки } & \multirow[b]{2}{*}{ Критерії } \\
\hline $\begin{array}{c}\text { за } \\
\text { шкалою } \\
\text { ECTS }\end{array}$ & $\begin{array}{c}\text { за } \\
\text { національною } \\
\text { шкалою }\end{array}$ & $\begin{array}{c}\text { за } \\
\text { шкалою } \\
\text { закладу }\end{array}$ & \\
\hline $\begin{array}{c}\mathrm{FX} \\
\text { “Незадовільно” }\end{array}$ & & $40-59$ & $\begin{array}{l}\text { Здобувач має значні прогалини в знаннях основного } \\
\text { навчального матеріалу дисципліни; припускає принципові } \\
\text { помилки при виконанні передбачених програмою завдань. }\end{array}$ \\
\hline $\begin{array}{c}\mathrm{F} \\
\text { “Незадовільно” }\end{array}$ & Незадовільно & $1-39$ & $\begin{array}{l}\text { Здобувач не має знань зі значної частини навчального } \\
\text { матеріалу; припускає принципові помилки при виконанні } \\
\text { більшості передбачених програмою завдань; не } \\
\text { спроможний самостійно засвоїти програмний матеріал. }\end{array}$ \\
\hline
\end{tabular}

Примітка: Підсумкова оцінка формується через розподіл балів між поточним контролем та заліком у співвідношенні $60 \%$ оцінки за практичні дії, семінарів, поточного контролю і $40 \%$ - результати заліку. 


\section{8. Питання до підсумкового контролю.}

1. Зміст і структура діяльності викладача.

2. Структура та функції діяльності викладача.

3. Сутнісні ознаки педагога ЗВО.

4. Структура педагогічної культури.

5. Основні компоненти педагогічної культури викладача.

6. Формування і розвиток педагогічної культури викладача ЗВО.

7. Зміст педагогічної діяльності викладача.

8. Педагогічна майстерність як найвищий рівень педагогічної діяльності.

9. Основні компоненти педагогічної майстерності.

10. Майстерність професійної діяльності педагога ЗВО.

11. Педагогічна культура та авторитет викладача 3ВО.

12. Шляхи формування та реалізація педагогічної майстерності.

13. Сутнісні ознаки педагога ЗВО.

14. Поняття про педагогічну культуру.

15. Компоненти педагогічної культури викладача.

16. Педагогічний досвід та педагогічні здібності як головні ознаки педагогічної культури.

17. Формування і розвиток педагогічної культури викладача ЗВО.

18. Педагогічна культура та авторитет викладача 3ВО.

19. Поняття педагогічної майстерності.

20. Головні складники педагогічної майстерності (гуманістична спрямованість; професійна компетентність; педагогічні здібності, педагогічна техніка) та їх характеристика.

21. Шляхи формування та реалізація педагогічної майстерності.

22. Педагогічна спрямованість як важлива умова входження у професійнопедагогічну діяльність.

23. Педагогічна майстерність праці педагога.

24. Психологічні особливості особистість.

25. Історія виникнення та еволюція поняття “педагогічна технологія".

26. Сутність і складові педагогічної технології.

27. Характеристика сучасних педагогічних технологій.

28. Модульно-рейтингова технологія навчання

29. Технологія проблемного навчання.

30. Групові технології та їх характеристика.

31. Ігрові технології та їх характеристика.

32. Гуманно-особистісна технологія (Ш. Амонашвілі).

33. Технологія особистісно-орієнтованого навчання (I. Якиманська).

34. Технологія індивідуалізації навчання (Інге Унт, В. Шадріков).

35. Технологія розвиваючого навчання (Д. Ельконіна - В. Давидова).

36. Технологія саморозвитку (М. Монтессорі). 
37. Технологія вільної праці (С. Френе).

38. Технологія рівневої диференціації.

39. Технологія майстерень.

40. Вольдорфська педагогіка (Р. Штейнер).

41. Технологія програмованого навчання.

42. Комп'ютерні технології.

43. Технології дистанційного навчання.

44. Освітні інформаційні технології.

45. Специфіка проведення лекції.

46. Специфіка проведення групового заняття.

47. Специфіка проведення семінару.

48. Специфіка проведення практичного заняття.

49. Специфіка проведення лабораторної роботи.

50. Поняття про педагогічну техніку, іiї структуру.

51. Зовнішня техніка педагога.

52. Внутрішня техніка педагога.

53. Способи та умови формування внутрішньої педагогічної техніки.

54. Шляхи удосконалення зовнішньої техніки педагога.

55. Майстерність педагога в управлінні собою, основи техніки саморегуляції.

56. Взаємозв'язок зовнішньої та внутрішньої техніки.

57. Педагогічна майстерність як мистецька дія.

58. Мистецтво педагогіки і педагогіка мистецтва.

59. Педагогічні функції мистецтва.

60. Педагогічний талант.

61. Поняття мова та мовлення.

62. Мовлення і комунікативна поведінка педагога.

63. Функції мовлення викладача з студентами.

64. Умови ефективності професійного мовлення педагога ЗВО.

65. Шляхи вдосконалення мовлення педагога.

66. Культура зовнішнього вигляду викладача.

67. Мовлення викладача як засіб педагогічної праці.

68. Шляхи вдосконалення мовлення педагога.

69. Основи мімічної та пантомімічної виразності викладача.

70. Характеристика викладача.

71. Права та обовязки викладача.

72. Професійні вимоги до особистості викладача.

73. Професійні та особистісні якості викладача: домінантні, супутні, небажані, неприйнятні.

74. Освітньо-кваліфікаційна характеристика викладача ЗВО.

75. Професіограма педагога.

76. Основи техніки саморегуляції. 


\section{Мельник Ю. Б.}

77. Поняття педагогічного спілкування, його особливості, функції, види.

78. Структура педагогічного спілкування.

79. Стилі педагогічного спілкування.

80. Розвиток комунікативних умінь і здібностей педагога ЗВО.

81. Сутність педагогічного спілкування.

82. Функції педагогічного спілкування.

83. Стилі педагогічного спілкування.

84. Комунікативні вміння, якими повинен оволодіти педагог ЗВО.

85. Вправи на контроль та корекцію правильної осанки, пози, руху.

86. Вправи на вироблення навичок невербальної поведінки педагога.

87. Вправи на розвиток розуміння експресій психічного стану особистості.

88. Вправи на розвиток основ мімічної та пантомімічної виразності.

89. Поняття про педагогічний такт педагога, його складові та умови вияву.

90. Категорія педагогічної етики у професійній діяльності педагога ЗВО.

91. Поняття про конфлікти у педагогічних ситуаціях, та шляхи їх вирішення.

92. Особливості взаємодії педагога з підлеглими, як мають "складний характер".

93. Особистість педагога як інструмент впливу в педагогічній взаємодії.

94. Способи комунікативного впливу: переконування та навіювання.

95. Стратегії взаємодії у спілкуванні як характеристика педагогічної взаємодії.

96. Шляхи формування педагогічного такту.

97. Конфліктні ситуації та педагогічні конфлікти, причини їх виникнення.

98. Основи педагогічного конфлікту та умови його запобігання.

99. Стратегії вирішення педагогічних конфліктів.

100. Професійне самовиховання педагога ЗВО. 


\section{ЛІТЕРАТУРА}

\section{Основна}

1. Абрамович С. Д., Чикарькова М. Ю. Риторика: навч. посіб. Львів: Світ, 2001. $240 \mathrm{c.}$

2. Бабіч Л. В., Кондратенко Г. М. Основи педагогічної майстерності: навч. посіб. Херсон: Айлант. 2002. 81 с.

3. Голік О. Б. Педагогічна майстерність: організаційно-управлінський аспект: навч. посіб. Донецьк: Ноулідж, 2010. 242 с.

4. Кривильова О. А. Підготовка майбутніх учителів до творчої діяльності: монографія. Донецьк: ТОВ «Юго-Восток, Лтд», 2008. 200 с.

5. Педагогічна майстерність: підручник/за ред. І. А. Зязюна. Київ: Вища школа, 2004. 422 c.

6. Педагогічна майстерність: Хрестоматія: навч. посіб./за ред. І. А. Зязюна. Київ: Вища школа, 2006. 606 с.

7. Педагогічна майстерність: підручник/Зязюн І. А. та ін.; за ред. I. А. Зязюна. Київ: СПД Богданова А. М., 2008. 376 с.

8. Пилипчик В. В. Розвиток педагогічної майстерності вчителя в предметних методиках навчання: монографія. Київ, 2007. 176 с.

9. Сисоєва С. О. Основи педагогічної творчості: підручник. Київ: Міленіум, 2006. $346 \mathrm{c}$.

10. Теслюк В. М. Основи педагогічної майстерності викладача вищої школи. підручник. Київ: Ліра-К, 2016. 340 с.

11. Теслюк В. М. Формування педагогічної майстерності майбутнього викладача: теоретико-методичний аспект: монографія. Київ: Ліра-К, 2018. 260 c.

\section{Допоміжна}

1. Про вищу освіту: Закон України від 01.07.2014 № 1556-VII // База даних "Законодавство України"/BP URL: https://zakon.rada.gov.ua/laws/show/1556-18/ed20180101\#Text

2. Про освіту: Закон України від 05.09.2017 № 2145-VIII // База даних “"Законодавство України"/BP URL: https://zakon.rada.gov.ua/laws/show/2145-19/ed20170905\#Text

3. Барбина Е. С. Педагогическое мастерство - искусство и наука быть человеком: уч.-метод. пособие. Київ, 1995. 105 с.

4. Бутенко В. Г. Естетичні орієнтири педагогічної праці. Етноестетика праці вчителя. 1995. С. 7-12.

5. Бутенко В. Г.Формирование педагогического мастерства учителя. Київ, 1991. $153 \mathrm{c}$.

6. Васянович Г. П. Педагогічна етика : навч.-метод. посіб. Львів: „Норма”, 2005. $344 \mathrm{c}$. 


\section{Мельник Ю. Б.}

7. Зязюн І. А. Педагогіка добра: ідеали та реалії: наук.-метод. посіб. Київ: МАУП, 2000. 312 c.

8. Лозова В. І., Троцко Г. В. Теоретичні основи виховання і навчання: навч. посіб. Харків: ОВС, 2002. 400 с.

9. Мельник Ю. Б. Методика підготовки до наукової доповіді. Теорія і практика управління соціальними системами: філософія, психологія, педагогіка, сочиіологія. 2012. № 1. С. 29-33.

10. Мельник Ю. Б. Педагогіка вищої школи: в схемах і таблицях: навч.-метод. посіб. Харків: НАНГУ, ХОГОКЗ, 2016. doi:10.26697/9789669726063.2016

11. Мельник Ю., Пипенко I. Запровадження педагогічної логістики у вищій школі. Науковий вісник Льотної академії. Сер. Педагогічні науки. 2017. Вип. 1. С. 100-105.

12. Мельник Ю. Б. Основи психотехнологій: прогр. та навч.-метод. матеріали. Вид. 3-е, перероб. і допов. Харків: ХНПУ, 2011. 64 с.

13. Освітні технології: навч.-метод. посіб./О.М. Пєхота. Київ: А.С.К., 2001. 256 с.

14. Педагогічна творчість, майстерність, професіоналізм у системі підготовки освітянських кадрів: здобутки, пошуки, перспективи: монографія/керівн. авт. кол. Н. В. Гузій. Київ: НПУ імені М. П. Драгоманова, 2015. 432 с.

15. Пехота Е. Н. Индивидуализация профессионально-педагогической подготовки учителя: монография/под ред. И. А. Зязюна. Київ: Вища школа, 1997. $281 \mathrm{c}$.

16. Синиця I. О. Педагогічний такт і майстерність учителя. Київ: Рад. школа, $1981.319 \mathrm{c}$.

17. Сухомлинський В. О. Сто порад учителеві. Київ: Рад.шк., 1988. 304 с.

18. Melnyk Y., Pypenko I. Innovative potential of modern specialist: the essence and content. Psychological and pedagogical problems of modern specialist formation/ed. by Yu. B. Melnyk. Warsaw: ANAGRAM; Kharkiv: KRPOCH, 2017. P. 9-16. doi:10.26697/9789669726094.2017.9

\section{Інформаційні ресурси}

1. Державна науково-педагогічна бібліотека України імені В. О. Сухомлинського: веб-сайт. URL: https://dnpb.gov.ua

2. Міністерство освіти і науки України: веб-сайт. URL: https://www.mon.gov.ua

3. Національна бібліотека України імені В. I. Вернадського: веб-сайт. URL: http://www.nbuv.gov.ua

4. Academia: website. URL: https://www.academia.edu

5. Google Scholar: website. URL: https://scholar.google.com

6. Scopus database: website. URL: https://www.scopus.com

7. Web of Science database: website. URL: https:// webofknowledge.com 
ПЕДАГОГІЧНА МАЙСТЕРНІСТЬ: СИЛАБУС навчально-методичний посібник

МЕЛЬНИК Юрій Борисович

DOI 10.26697/SRI.KRPOCH/Melnyk.Yu.1.2018

Видається в авторській редакції

Відповідальний випусковий: Ю. Б. Мельник

Комп'ютерне складання та верстання: Ю. Б. Мельник

Формат 80х64 $1 / 6$

Гарн. “Тimes”. Папір для мн. ап. Друк цифровий.

Ум. друк. арк. 1,4. Зам. № 2-1.

Тираж 100 пр.

Науково-дослідний інститут ХОГОКЗ

https://institute.culturehealth.org

Харківська обласна громадська організація “Культура Здоров'я"

Україна, 61105, м. Харків, пров. Забайкальський, 6/6.

Emails: CultureHealth@ukr.net; KOSOCH@gmail.com; https://www.culturehealth.org; T/F: +38 0577757523.

Свідоцтво про державну реєстрацію видавництва ДК № 4387 від 10.08.2012 